\title{
GLU- AND LYS-FORMS OF PLASMINOGEN DIFFERENTIALLY AFFECT PHOSPHATIDYLSERINE EXPOSURE ON THE PLATELET SURFACE
}

\author{
D. D. ZHERNOSSEKOV, Y. M. ROKA-MOIIA, A. O. TYKHOMYROV, \\ M. M. GUZYK, T. V. GRINENKO
}

Palladin Institute of Biochemistry, National Academy of Sciences of Ukraine, Kyiv; e-mail: chemikdd@mail.ru

\begin{abstract}
Plasminogen/plasmin system is known for its ability to support hemostatic balance of blood. However, plasminogen may be considered as an adhesive ligand and in this way could affect the functioning of blood cells. We showed that exogenous Lys-plasminogen, but not its Glu-form, inhibited platelet aggregation and suppressed platelet $\alpha$-granule secretion. The aim of this work was to investigate the influence of Glu-and Lysform of plasminogen on the formation of platelet procoagulant surface using phosphatidylserine exposure as a marker. Human platelets were obtained from human platelet-rich plasma (donors were healthy volunteers, men aged 30-40 years) by gel-filtration on Sepharose 2B. Phosphatidylserine exposure on the platelet surface was evaluated by flow cytometry with FITC-conjugated annexin A5. Glu- and Lys-plasminogen have different impact on the platelet functioning. Exogenous Lys-plasminogen has no significant effect on phosphatidylserine exposure, while Glu-plasminogen increases phosphatidylserine exposure on the surface of thrombin- and collagen-activated human platelets. Glu-plasminogen can be considered as a co-stimulator of agonist-induced platelet secretion and procoagulant surface formation. Meanwhile effects of Lys-plasminogen are probably directed at platelet-platelet interactions and not related to agonist-stimulated pro-apoptotic changes. The observed different effects of Glu-and Lys-plasminogen on phosphatidylserine exposure can be explained by their structural peculiarities.
\end{abstract}

Key word s: Glu- and Lys-plasminogen, phosphatidylserine exposure, platelets.

$\mathrm{P}$ lasminogen/plasmin system plays the key role in degradation of fibrin clots and supports hemostatic balance of blood. However, it was reported that plasminogen can be considered as an adhesive ligand for integrins and modulate functioning of blood cells [1]. There are two forms of plasminogen, which differ according to their structure and functional role in hemostasis system. The native form of the molecule, Glu-plasminogen, possesses closed conformation and it is the main form of plasminogen circulating in plasma. Lys-plasminogen is a partially degraded form, which is formed due to catalytic action of plasmin on Glu-plasminogen. Lysplasminogen is not present in blood under physiological conditions but a low amount of this form was detected in blood of patients undergoing thrombolytic therapy with tissue plasminogen activator [2]. It was shown that Lys-plasminogen has more open conformation and possesses more affinity towards fibrin and membrane receptors [3]. It is known that both forms of plasminogen are able to bind to platelet surface, however, Lys-plasminogen binds to platelets with higher affinity [4]. In our previous investigations, we showed that exogenous Lys-plasminogen inhibits platelet aggregation and suppresses platelet $\alpha$-granule secretion, meanwhile the native form of plasminogen has no significant influence on the above-mentioned processes $[5,6]$. We suggested that plasminogen effects, which were shown during platelet aggregation and secretion, can be observed at the step of procoagulant phospholipid membrane formation, i.e. phosphatidylserine exposure on the platelet surface. The present work is aimed to study plasminogen influence on phosphatidylserine exposure on the surface of platelets activated by thrombin or collagen.

\section{Materials and Methods}

Plasminogen preparation. Glu-plasminogen was purified from fresh blood plasma of healthy volunteers and Lys-plasminogen was isolated from Cohn fraction III2,3. Research protocols were ap- 
proved by the Ethical Committee of Palladin Institute of Biochemistry of NASU (from $3^{\text {rd }}$ of November 2014, protocol N 10).

Lysine-sepharose chromatography was used in both cases [7]. All preparations of plasminogen had no spontaneous plasmin activity. Plasminogen preparations in all experiments were used at final concentration $1.2 \mu \mathrm{M}$.

Platelet aggregation. Intact platelets were obtained from human platelet-rich plasma by gel-filtration on Sepharose 2B [8]. Platelet aggregation was measured by optical aggregometry (aggregometer Solar AT-02, Belorussia). All assays were performed within 60-80 min after platelet collection. Thrombin (Sigma Aldrich, USA) at final concentration 1 unit $\mathrm{NIH} / \mathrm{ml}$ and collagen (Tekhnologia Standard, Russia) at final concentration $1.25 \mathrm{mg} / \mathrm{ml}$ were used to stimulate platelets. Experimental data were statistically analyzed using software MS Office Excel 2007 and Agregometr 2.01.

Flow cytometry. To investigate plasminogen effects on phosphatidylserine exposure flow cytometry with FITC-conjugated annexin A5 (Sigma Aldrich, USA) was used. Washed platelets $\left(2.5 \times 10^{6}\right)$ were transferred into $100 \mu \mathrm{l}$ of $20 \mathrm{mM}$ HEPES buffer, pH 6.8, containing $137 \mathrm{mM} \mathrm{NaCl}, 4 \mathrm{mM}$ $\mathrm{KCl}, 0.2 \mathrm{mM} \mathrm{MgCl}, 0.2 \%$ glucose and $0.2 \%$ BSA. The platelets were incubated with Glu- or Lys-plasminogen for $3 \mathrm{~min}$ at $22-25^{\circ} \mathrm{C}$ with or without further incubation with thrombin or collagen for $5 \mathrm{~min}$ at $22-25{ }^{\circ} \mathrm{C}$. Intact platelets were served as control. After incubation, platelets were washed by $0.05 \mathrm{M}$ PBS, $\mathrm{pH} 7.4$, with $0.13 \mathrm{M} \mathrm{NaCl}$ by centrifugation at $1,000 \mathrm{~g}$ at $25^{\circ} \mathrm{C}$. Platelets were resuspended in $1.5 \mathrm{ml}$ of $0.05 \mathrm{M}$ PBS, pH 7.4, with $0.13 \mathrm{M} \mathrm{NaCl}$, according with manufacturer's instruction. FITCconjugated annexin A5 was added to all samples and suspension was incubated in the darkness at room temperature for $30 \mathrm{~min}$. Fluorescence intensity was monitored by Coulter Epics flow cytometer (Beckman Coulter, USA) via FL1 channel (515-535 nm). Annexin A5 exposure on the platelet surface was estimated using two parameters: 1) the percentage of annexin A5-positive cells of total cell number in the sample 2) the fluorescence intensity which was detected via FL1 channel (515-535 nm). To obtain statistically significant results no less than 15,000 events were analyzed for each sample. The measurement of cytometric parameters in each group of cells was carried out in duplicate, and the mean value was calculated based on the values obtained from all donors.
The results were graphically presented using "FCS Express V3" (De Novo Software, USA). The data were expressed as mean \pm SD. Statistical analysis of the results was performed with using of Student's $t$-test, the difference was considered as significant at $P<0.05$.

\section{Results and Discussion}

For better presentation of flow cytometry results two gated regions were created. Gated region M1 was set to estimate the population of annexin A5-positive platelets and M2 marker was created around the clearly identifiable sub-population showing high level of annexin A5 binding. (Fig. 1). We found that among intact platelets there was only small amount of cells exposing phosphatidylserine on their surface $(3.6 \pm 1.3 \%)$, see Fig. 2. Thrombin stimulation (1 unit $\mathrm{NIH} / \mathrm{ml}$ ) increased the amount of annexin A5 positive cells in 8.6 times $(31 \pm 3.9 \%)$. It has to be noted that large proportion of the platelets (2/3) displayed high level of annexin A5 binding. Framing such sub-population during thrombin activation was shown at the dot graph (see Addendum 1): dot density was significantly shifted on the right by axis FL1 LOG, indicating the high fluorescence intensity of thrombin-stimulated platelets. The average fluorescence of this sub-population was 1.52 times higher than in the whole population of annexin A5-positive cells. Thrombin stimulation led to phosphatidylserine exposure and as a result annexin A5 binding on the platelet surface. The proportion of annexin A5-positive platelets became larger and it was noticed the appearance of sub-population of platelets with intensive fluorescence.

Incubation with Glu-plasminogen followed by thrombin stimulation resulted in the increase of population of annexin A5-positive platelets (in 1.6 times). Under these conditions, the effect of Lysplasminogen was more moderate. In case of Lysplasminogen effect, the changes were related with the sub-population of platelets showing low level of annexin A5 binding (Addendum 1, group "Lys-Pg + Thr"). It has to be noted that plasminogen itself, in the absence of stimulation, had no influence on platelet functions.

Collagen was a potent stimulator of phosphatidylserine exposure as the amount of annexin A5binding platelets increased on $55.3 \pm 8.8 \%$ (Fig. 3, A). Most annexin A5-positive cells possessed high fluorescence. The fluorescence intensity of these cells was 6 times higher as compared to this one 


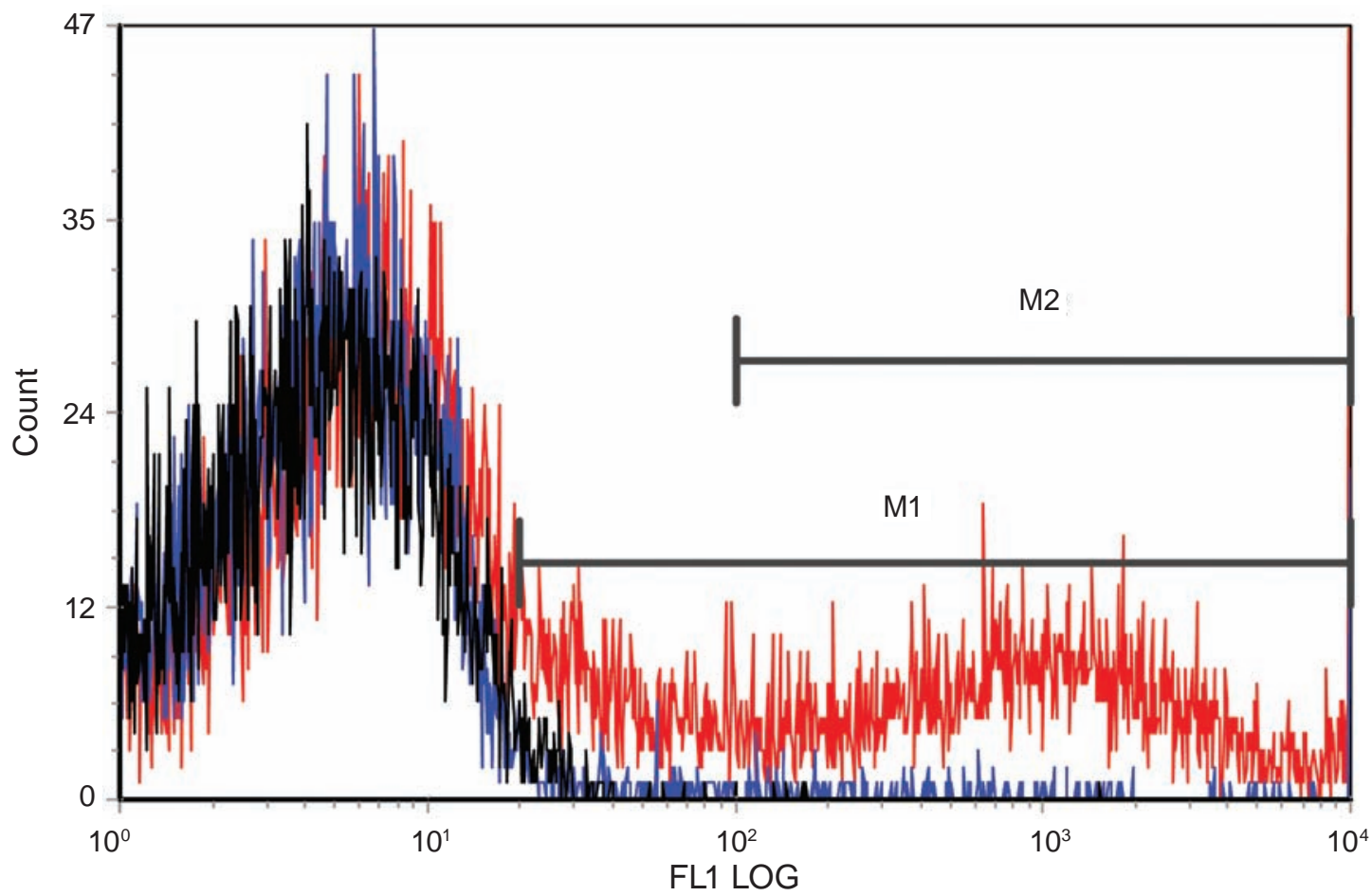

Fig. 1. Thrombin effect on annexin A5 binding by washed human platelets (typical histogram). M1 - population of annexin A5-positive platelets, M2 - sub-population of platelets showing high level annexin A5 binding. FL1 LOG - the log of FITC-fluorescence intensity: - - intact platelets without annexin A5; $\square$ - thrombinstimulated platelets with added annexin A5; $\square$-intact platelets with added annexin A5

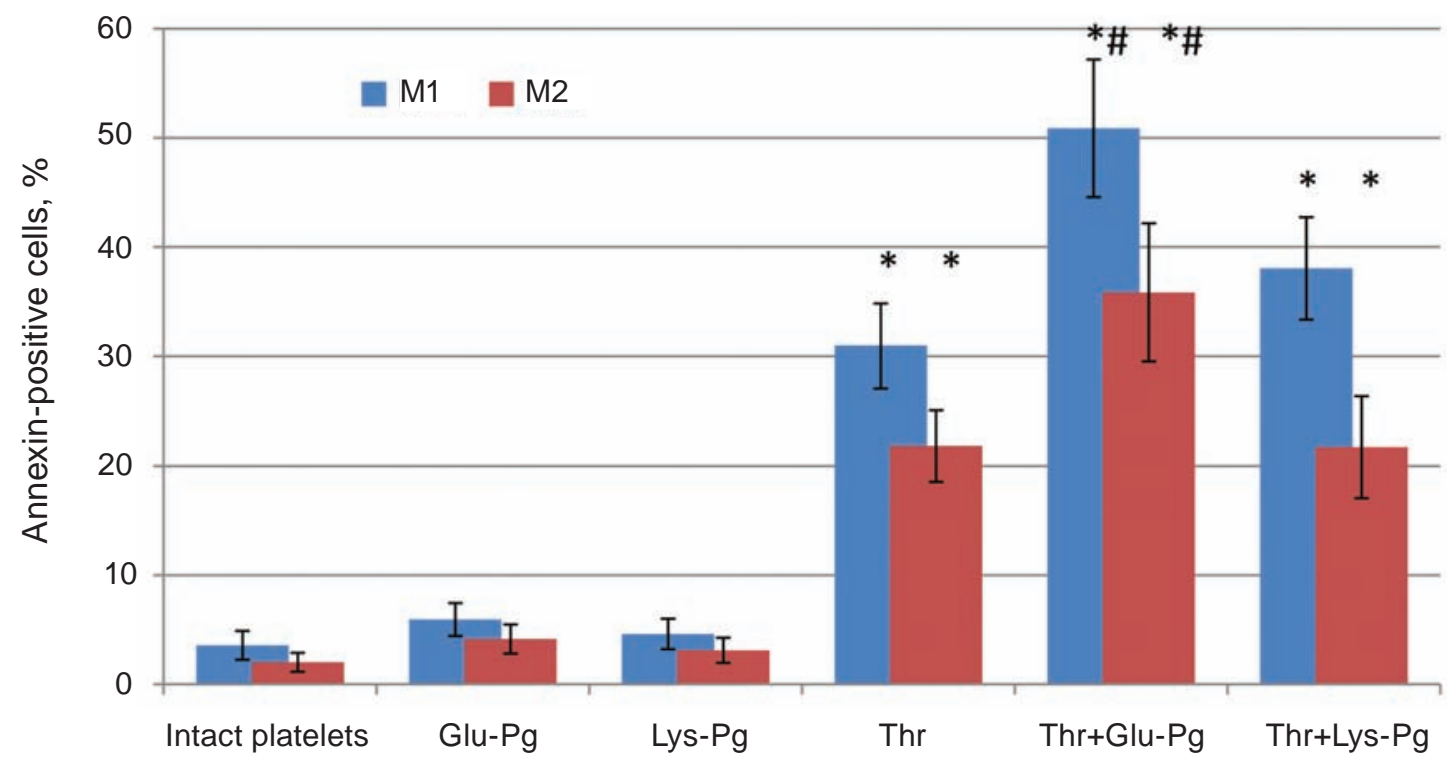

Fig. 2. Effects of Glu- and Lys-plasminogen on annexin A5 exposure on thrombin-stimulated platelets $(n=4)$. M1 - population of annexin A5-positive platelets, M2 - sub-population of platelets showing high level annexin A5 binding. Difference in the compared groups is statistically significant $(P<0.05)$ : * compared to the group "Intact platelets", \# compared to the group "Thrombin" 
for population of intact cells (Fig. 3, B). The subpopulation of platelets showing high level of annexin A5 binding was framed (Addendum 2, "Collagen"): dot density was significantly shifted on the right by axis FL1 LOG, indicating the high fluorescence intensity of collagen-stimulated platelets. Vertical division of annexin A5-positive cells showed the increasing granularity under collagen stimulation. It should be noted that the proportion of the platelets showing high level of annexin A5 binding was even larger $(4 / 5)$ than in case of thrombin. Pre-incubation of platelets with Glu-plasminogen enhanced the collagen effect: the number of annexin A5-positive platelets was not significantly changed, however, the fluorescence intensity of these cells increased at least in two times. Incubation with Glu-plasminogen induced the formation of the larger population of platelets showing high level of annexin A5 binding. Lysplasminogen under these conditions had no effects.

The relationship between plasminogen binding to cells and phosphatidylserine exposure has been earlier described in the literature [9-11]. O'Mullane et al. showed that in the presence of apoptotic factors (thrombin is considered as one of them) exogenous Glu-plasminogen considerably increases phosphatidylserine exposure on the surface of cells of monocyte culture U 937 [12]. According to our data, thrombin is not only stimulates platelet activa-

A

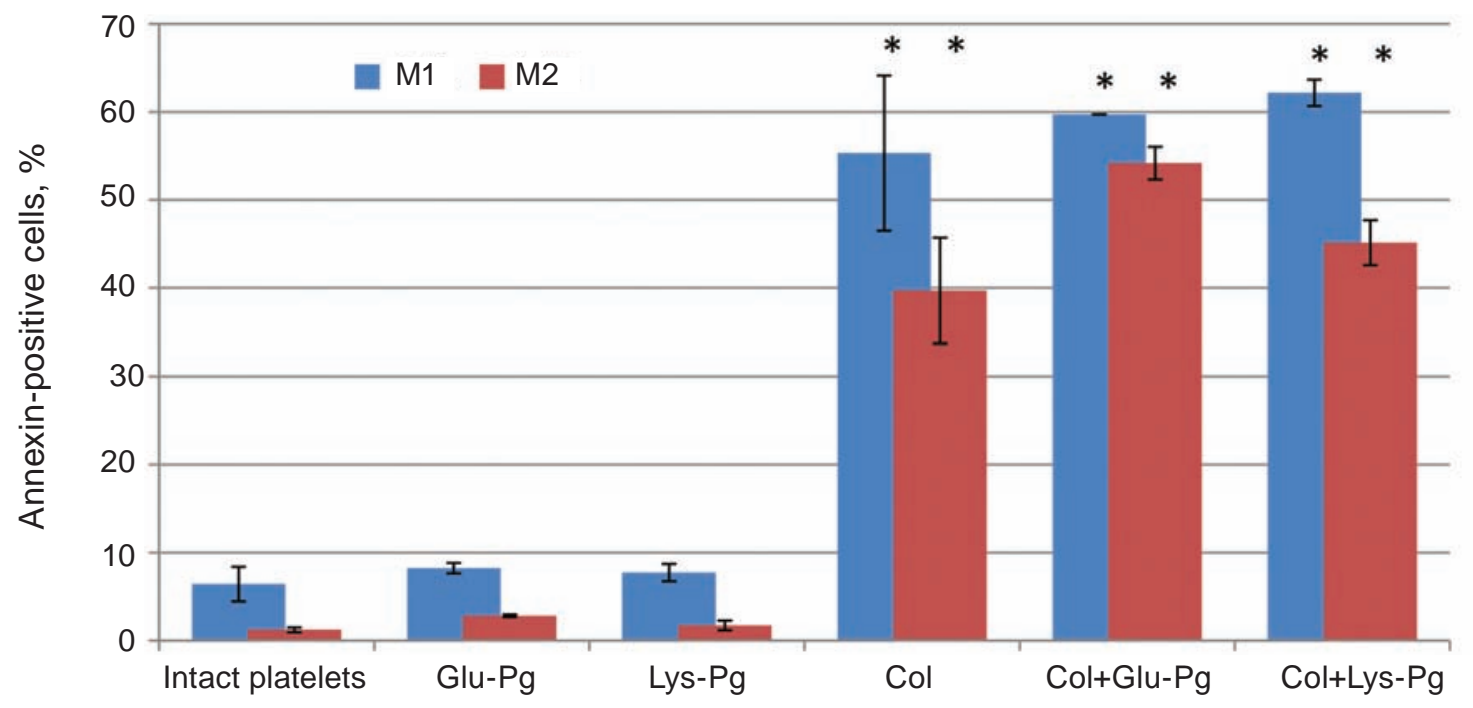

B

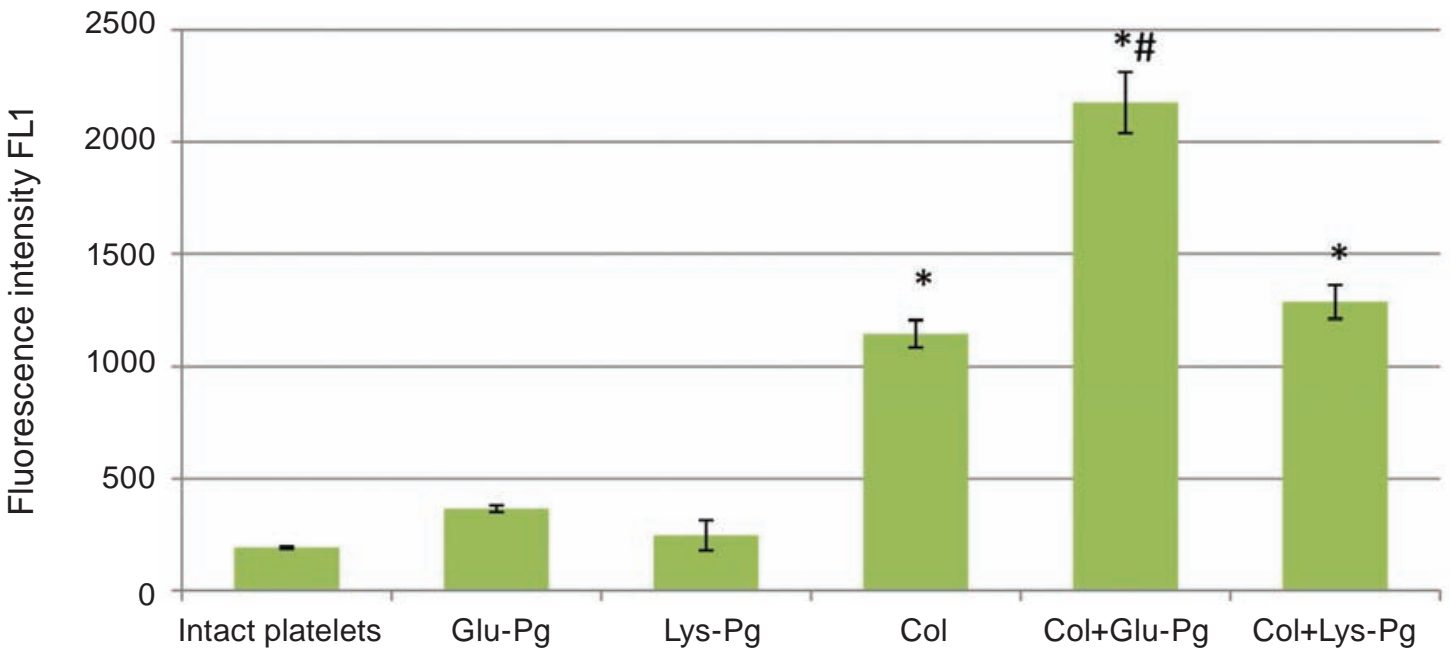

Fig. 3. Effects of Glu- and Lys-plasminogen on annexin A5 exposure on collagen-stimulated platelets ( $n=3)$ : A-amount of annexin A5 positive cells, B-fluorescence intensity. M1-population of annexin A5-positive platelets; M2 - sub-population of platelets showing high level of annexin A5 binding. Difference in the compared groups is statistically significant $(P<0.05)$ : * compared to the group "Intact platelets", \# compared to the group "Collagen" 

the formation of procoagulant surface. Thrombin stimulation led to activation of surface receptors GP $\mathrm{Ib}$ and IIbIIa and triggers the chain of events which leads to the formation of procoagulant surface (see Fig. 4). As it was previously shown the inhibition of these receptors on the platelet surface by specific antibodies blocked the exposure of procoagulant activity on platelets [13].

According to our data, Glu-plasminogen can be considered as a co-stimulator of agonist-induced platelet secretion and procoagulant surface formation. Effects of Lys-plasminogen are probably directed at platelet-platelet interactions and not related to agonist-stimulated pro-apoptotic changes. We showed that the stimulating effect of Glu-plasminogen in exposure of phosphatidylserine was more pronounced under thrombin stimulation. It can be explained by the fact that these agonists realize their stimulating effects through different ways. Dormann et al. suggested that in case of thrombin, platelet gly- tion and secretion of $\alpha$-granules, but also potentiates

coprotein GP Ib plays an essential role in the formation of platelet procoagulant surface [13]. In case of collagen, this glycoprotein is not involved.

The obtained results highlight the possibility of the practical use of two forms of plasminogen in therapeutic practice. As it was noted before, Lysplasminogen in complex with streptokinase can be considered as a tool for the treatment of patients with deep vein thrombosis [14] and administration of Glu-plasminogen improves the healing of chronic diabetes wounds in a mouse model of diabetes [15]. Besides, it was shown that platelets in type 2 diabetic individuals adhere to vascular endothelium and aggregate more readily than those in healthy people [16]. Lys-plasminogen, which shows its anti-aggregation effect, seems to be a good candidate for correlation of such pathological state.

In conclusion, the obtained results indicate the different effects of Glu- and Lys-plasminogen on platelet functions. The precise mechanisms of these effects need further investigation and will be clari-

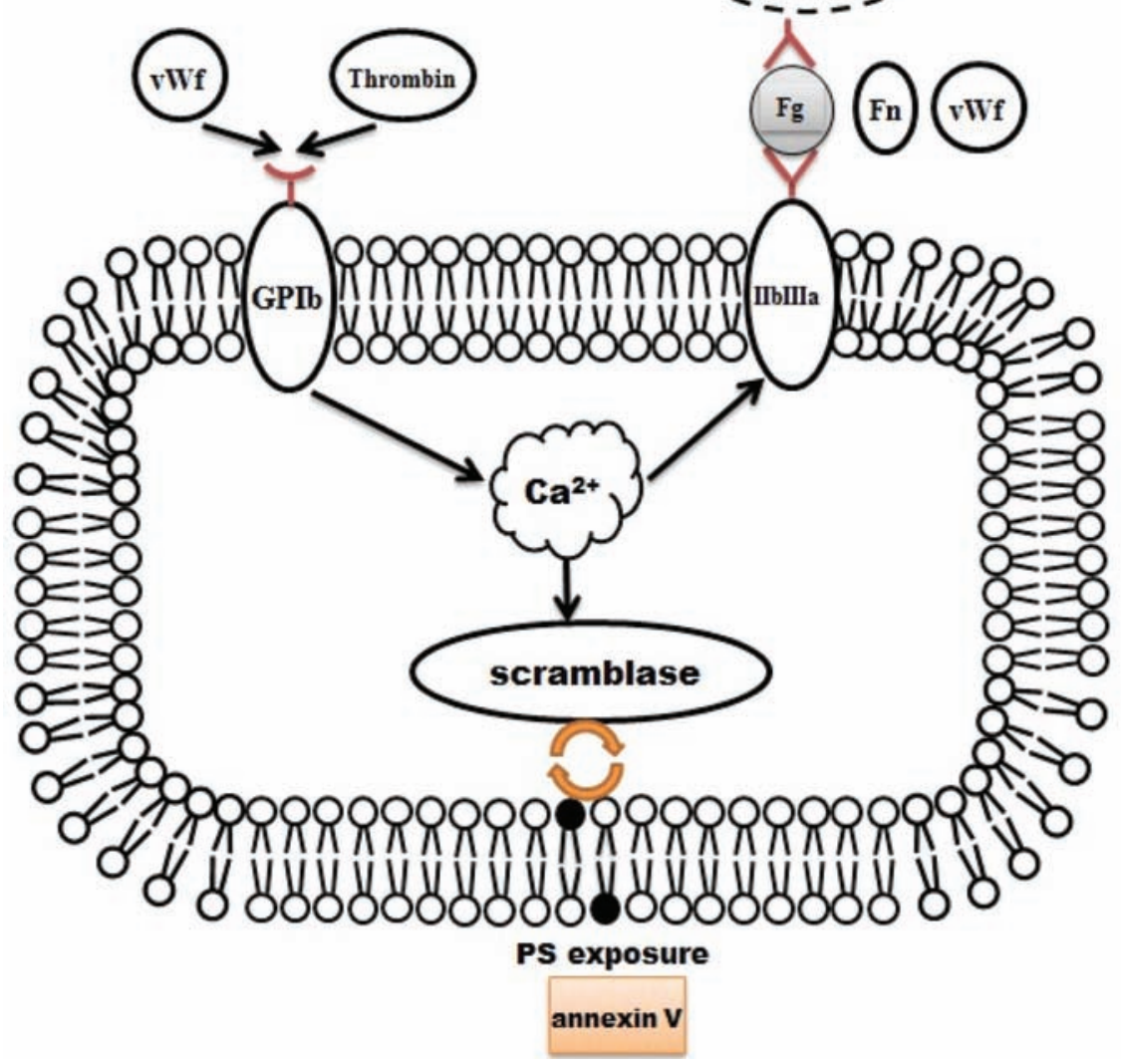

Fig. 4. Thrombin influence on platelet activation and phosphatidylserine exposure. GP Ib - integral platelet glycoprotein, PS - phosphatidylserine; IIbIIIa - platelet integrin; adhesive ligands for IIbIIIa: vWf - von Willebrand factor, Fg-fibrinogen, Fn-fibronectin 

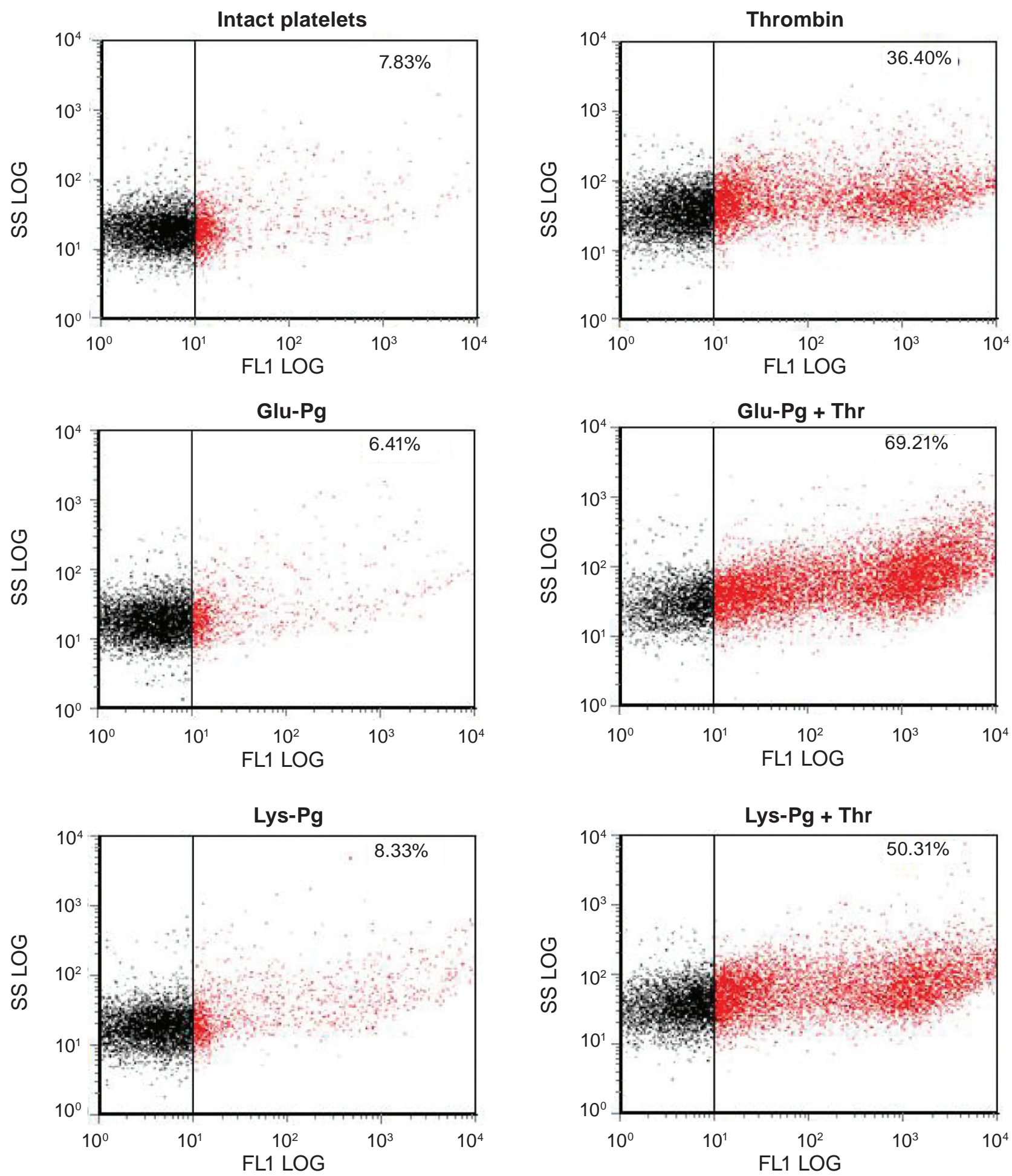

\section{Addendum 1}

Addendum 1. Effects of Glu- and Lys-plasminogen on annexin A5 exposure under thrombin stimulation (typical dot graph): SS LOG - the log side scatter (platelet granularity), FL1 LOG - the log of FITC-fluorescence intensity. Red colour here and after-annexin A5 positive cells 

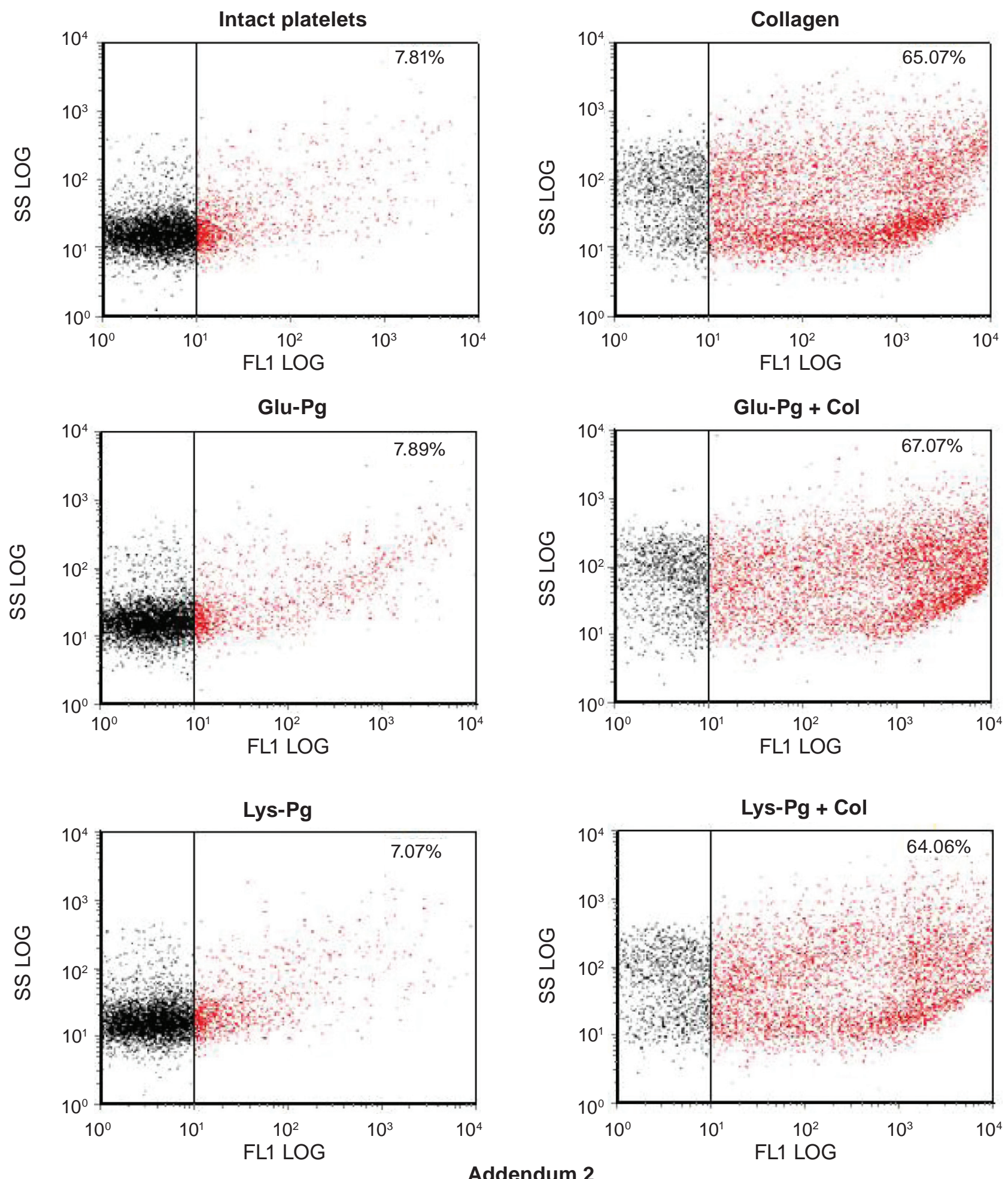

\section{Addendum 2}

Addendum 2. Effects of Glu- and Lys-plasminogen on annexin A5 exposure under collagen stimulation (typical dot graph): SS LOG - the log side scatter (platelet granularity), FL1 LOG - the log of FITC-fluorescence intensity 
fied in the future studies. However, we suggest that the conformational differences between native and truncated forms of plasminogen molecules could play the principal role for realization of above-mentioned effects.

Funding This work was supported by the Grant of National Academy of Science of Ukraine $0113 U 003203$.

\section{GLU- TA LYS-ФОРМИ ПЛАЗМІНОГЕНУ ПО РІЗНОМУ ВПЛИВАЮТЬ НА ЕКСПОНУВАННЯ ФОСФАТИДИЛСЕРИНУ НА ПОВЕРХНІ ТРОМБОЦИТІВ}

\section{Д. Д. Жерносєков, Я. М. Рока- \\ Мойя, А. О. Тихомиров, М. М. Гузик, \\ Т. В. Гриненко}

\author{
Інститут біохімії ім. О. В. Палладіна \\ НАН України, Київ; \\ e-mail: chemikdd@mail.ru
}

Плазміноген/плазмінова система відповідає за підтримку гемостатичного балансу крові. Водночас плазміноген може виступати як адгезивний ліганд і таким чином впливати на функціонування клітин крові. Нами було показано, що екзогенний Lys-плазміноген, на відміну від Glu-форми, призводить до інгібування тромбоцитарної агрегації та пригнічує секрецію $\alpha$-гранул тромбоцитів. Мета цієї роботи дослідити вплив Glu- та Lys-форм плазміногену на формування прокоагулянтної поверхні тромбоцитів, використовуючи як маркер експонування фосфатидилсерин на тромбоцитах. Тромбоцити отримували зі збагаченої тромбоцитами плазми (здорові донори-волонтери, чоловіки віком 30-40 років) методом гель-хроматографії на сефарозі 2B. Експонування фосфатидилсерину на поверхні тромбоцитів оцінювали методом протокової цитофлуориметрії за допомогою ФІТЦ-кон'югованого анексину А5. Показано, що Glu- та Lys-форми плазміногену спричиняли різний вплив на функціонування тромбоцитів. Екзогенний Lys-плазміноген не мав істотного впливу на експонування фосфатидилсерину, в той час як Glu-плазміноген за цих умов призводив до підвищеного експонування фосфатидилсерину на поверхні тромбоцитів активованих тромбіном або колагеном. Зроблено висновок щодо можливої ролі
Glu-плазміногену як ко-стимулятора агоністіндукованої секреції тромбоцитів, так і стимулятора формування прокоагулянтної поверхні. Ефекти Lys-плазміногену ймовірно спрямовані на міжтромбоцитарну взаємодію і не пов'язані 3 агоніст-стимульованими про-апоптичними змінами. Різний ефект Glu- та Lys- форм плазміногену може бути пояснений структурними особливостями відповідних форм зимогену.

Ключов г слова: Glu- та Lysплазміноген, експонування фосфатидилсерину, тромбоцити.

\section{GLU- И LYS-ФОРМЫ \\ ПЛАЗМИНОГЕНА ОКАЗЫВАЮТ \\ РАЗНОЕ ВЛИЯНИЕ НА \\ ЭКСПОНИРОВАНИЕ \\ ФОСФАТИДИЛСЕРИНА НА ПОВЕРХНОСТИ ТРОМБОЦИТОВ}

\author{
Д. Д. Жерносеков, Я. М. Рока- \\ Мойя, А. А. Тихомиров, М. М. Гузик, \\ T. В. Гриненко \\ Институт биохимии им. А. В. Палладина \\ НАН Украины, Киев; \\ e-mail: chemikdd@mail.ru
}

Плазминоген/плазминовая система отвечает за поддержание гемостатического баланса крови. В то же время плазминоген может выступать в роли адгезивного лиганда и таким образом влиять на функционирование клеток крови. Нами было показано, что экзогенный Lys-плазминоген, в отличие от Glu-формы, способствует ингибированию тромбоцитарной агрегации и подавляет секрецию $\alpha$-гранул тромбоцитов. Цель настоящей работы - исследовать влияние Glu- и Lys-формы плазминогена на формирование прокоагулянтной поверхности тромбоцитов, используя в качестве маркера экспонирование фосфатидилсерина на тромбоцитах. Тромбоциты получали из обогащенной тромбоцитами плазмы (здоровые доноры-добровольцы, мужчины 30-40 лет) методом гельхроматографии на сефарозе 2В. Экспонирование фосфатидилсерина на поверхности тромбоцитов оценивали методом проточной цитофлуориметрии с помощью ФИТЦ-конъюгированного аннексина A5. Показано, что, Glu- и Lys-формы плазминогена проявляли разный эффект на функционирование тромбоцитов. Экзогенный 
Lys-плазминоген не оказывал существенного влияния на экспонирование фосфатидилсерина, в то время как Glu-плазминоген в этих условиях приводил к повышению уровня экспонированного фосфатидилсерина на поверхности тромбоцитов активированных тромбином или коллагеном. Сделали вывод о возможной роли Glu-плазминогена как ко-стимулятора агонист-индуцированной секреции тромбоцитов и стимулятора формирования прокоагулянтной поверхности. Эффекты Lys-плазминогена вероятно направлены на межтромбоцитарные взаимодействия и не связаны с агонист-стимулированными про-апоптическими изменениями. Разный эффект Glu- и Lys- форм плазминогена может быть объяснен структурными особенностями соответствующих форм зимогена.

Ключевы е слов а: Glu- и Lysплазминоген, экспонирование фосфатидилсерина, тромбоциты.

\section{References}

1. Lishko VK, Novokhatny VV, Yakubenko VP, Skomorovska-Prokvolit HV, Ugarova TP. Characterization of plasminogen as an adhesive ligand for integrins alphaMbeta2 (Mac-1) and alpha5beta1 (VLA-5). Blood. 2004; 104(3): 719726.

2. Holvoet P, Lijnen HR, Collen D. A monoclonal antibody specific for Lys-plasminogen. Application to the study of the activation pathways of plasminogen in vivo. $J$ Biol Chem. 1985; 260(22): 12106-12111.

3. Miles LA, Castellino FJ, Gong Y. Critical role for conversion of glu-plasminogen to Lys-plasminogen for optimal stimulation of plasminogen activation on cell surfaces. Trends Cardiovasc Med. 2003; 13(1): 21-30.

4. Miles LA, Dahlberg CM, Plow EF. The cellbinding domains of plasminogen and their function in plasma. J Biol Chem. 1988; 263(24): 11928-11934.

5. Tykhomyrov AA, Zhernossekov DD, RokaMoya YM., Diordieva SI, Grinenko TV. The effects of Lys-plasminogen on human platelet secretion. Fiziol Zhurn. 2015; 61(6): 26-34. (In Ukranian).
6. Roka-Moya YM, Zhernossekov DD, Grinenko TV. Plasminogen/plasmin influence on platelet aggregation. Biopolym Cell. 2012; 28(5): 352-356.

7. Deutsch DG, MertzET. Plasminogen: purification from human plasma by affinity chromatography. Science. 1970; 170(3962): 1095-1096.

8. Kruger LA, Barnard MR, Frelinger AL III, Furman ML, Michelson AD. Immunophenotypic analysis of platelets. Current protocols in cytometry. New York, John Wiley and Sons; 2002.

9. Zhernossekov DD, Roka-Moiia YM, Grinenko TV. Extracellular annexins in hemostasis system. Biopolym Cell. 2016; 32(2): 98-104.

10. Whyte CS, Swieringa F, Mastenbroek TG, Lionikiene AS, Lancé MD, van der Meijden PE, Heemskerk JW, Mutch NJ. Plasminogen associates with phosphatidylserine-exposing platelets and contributes to thrombus lysis under flow. Blood. 2015; 125(16): 2568-2578.

11. Das R, Plow EF. Phosphatidylserine as an anchor for plasminogen and its plasminogen receptor, histone $\mathrm{H} 2 \mathrm{~B}$, to the macrophage surface. J Thromb Haemost. 2011; 9(2): 339-349.

12. O'Mullane MJ, Baker MS. Elevated plasminogen receptor expression occurs as a degradative phase event in cellular apoptosis. Immunol Cell Biol. 1999;7 7(3): 249-255.

13. Dörmann D, Clemetson KJ, Kehrel BE. The GPIb thrombin-binding site is essential for thrombin-induced platelet procoagulant activity. Blood. 2000;96(7): 2469-2478.

14. Kakkar VV, Scully MF. Intermittent plasminogen-streptokinase treatment of deep vein thrombosis. Haemostasis. 1988; 18(Suppl 1): 27-38.

15. Shen $Y$, Guo $Y$, Mikus $P$, Sulniute $R$, Wilczynska M, Ny T, Li J. Plasminogen is a key proinflammatory regulator that accelerates the healing of acute and diabetic wounds. Blood. 2012; 119(24): 5879-5887.

16. Vinik AI, Erbas T, Park TS, Nolan R, Pittenger GL. Platelet dysfunction in type 2 diabetes. Diabetes Care. 2001; 24(8): 1476-1485.

Received 31.01.2017 